\title{
DOES REAL ESTATE TRANSPARENCY MATTER FOR FOREIGN REAL ESTATE INVESTMENTS?
}

\author{
Mohammad Reza FARZANEGAN a,b, Hassan GHOLIPOUR FEREIDOUNI ${ }^{\text {c,* }}$ \\ ${ }^{a}$ Department of the Middle East Economics, Center for Near and Middle Eastern Studies (CNMS), \\ Philipps-University of Marburg, Deutschhausstraße 12, D-35032 Marburg, Germany and Marburg \\ Center for Institutional Economics (MACIE), Philipps-University of Marburg, Barfüßertor 2, D-35037 \\ Marburg, Germany \\ ${ }^{b}$ CESifo GmbH (Munich Society for the Promotion of Economic Research), Poschinger 5, D-81679 \\ München, Germany \\ c Department of Accountancy, Economics and Finance, Swinburne Business School, Faculty of Business \\ and Law, Swinburne University of Technology, Melbourne, Victoria 3122, Australia
}

Received 11 July 2012; accepted 9 July 2013

\begin{abstract}
The purpose of this paper is to examine the impact of real estate transparency $(R E T)$ on foreign real estate investments (FREI). Most of the previous studies have argued that the free flow of information and the fair and consistent application of local property laws could attract greater amounts of FREI. Using observations from 32 countries covering 2004, 2006, 2008 and 2010 and applying fixed-effect and the generalized method of moments $(G M M)$ techniques, our empirical results reveal that RET is not a major determinant of FREI. However, we find that the effect of RET on FREI is dependent on its interaction with the level of income implying that the higher the level of income in the host country, the higher the effect of RET on FREI. Finally, the results show that foreign direct investment (FDI) in other sector, market size and property prices are important determinants of FREI.
\end{abstract}

KEYWORDS: Real estate transparency; Foreign real estate investments; Income; Property prices; Panel data

\section{INTRODUCTION}

A transparent real estate market is a market fairly free from corruption and it has readily available information and operates in a fair and consistent manner (JLL ${ }^{1}$ 2006). In other words, a transparent real estate market is completely open and clearly organized, operates in a legal and regulatory framework characterized by a consistent approach to the enforcement of published rules and planning regulations, respects private property rights and has relatively low transaction and information costs (Triantafyllopoulos 2006).

Several observers argue that the higher level of real estate transparency (RET) attracts greater amounts of foreign real estate investments (FREI) (e.g. Schulte et al. 2005; JLL 2006, 2010). It is because $R E T$ is a powerful incentive for encourag-

\footnotetext{
1 Jones Lang LaSalle is a financial and professional services firm specializing in real estate services and investment management.
}

\footnotetext{
* Corresponding author. E-mail: hgholipour@swin.edu.au
}

ing the free flow of information and the fair and consistent application of local property laws (JLL 2010). Therefore, transparent markets can create confidence and be attractive to domestic and international investors (Schulte et al. 2005).

However, investors' interest in less transparent markets like Japan, China and Mexico is rising rapidly (JLL 2006). JLL $(2008,2010)$ noted that high levels of transparency do not eliminate risks for investors and guarantee a strong investment return. JLL (2008) also shows that the association between the level of transparency and the growth in cross-border real estate transaction volumes is not strong. For example, Japan and South Korea recorded solid increases in cross-border real estate transaction volumes in 2006-2007, in spite of minimal improvements in RET (JLL 2008). It is argued that rather than transparency enhancements being the key determinant of capital flows, property market fundamentals are the main driving force behind cross-border transactions. In other words, 
foreign investors in property sector may not appreciate the transparent market while they stress returns on capital and other property market factors.

Yet we do not know the impact of $R E T$ on FREI. We explore our hypothesis using a panel of 32 countries for 2004, 2006, 2008 and 2010. This study contributes to the existing literature in several ways. First, while there has been a series of conceptual, qualitative and descriptive papers published in this area (e.g. Triantafyllopoulos 2006; D'Arcy 2009; Adair et al. 2006), very few empirical works have examined the effect of $R E T$ on FREI by applying a panel data approach. Panel data give more informative data, more variability, less co-linearity among the variables, more degree of freedom and more efficiency. With additional, more informative data researchers can produce more reliable parameter estimates (Baltagi 2005). Second, while FREI is a large component of FDI in services, currently there are very few analyses of determinants of FREI across a broad set of countries. Third, our paper is the first attempt to utilize the Jones Lang LaSalle's Real Estate Transparency Index in a FREI study.

The paper is organized as follows. Section 2 provides some stylized facts for the RET and FREI in the countries under study. Section 3 reviews some of the relevant studies. In Section 4, besides the RET, we identify the factors that will be relevant for our econometric investigation, drawing from the empirical and theoretical literature. In Section 5, we specify the empirical model, explain the methodology and present the results. Finally, Section 6 concludes.

\section{REAL ESTATE TRANSPARENCY AND FOREIGN REAL ESTATE INVESTMENTS: STYLIZED FACTS}

This section sets the scene for the empirical analysis that follows by presenting some stylized facts for RET and FREI.

Over the period of study (2004-2010), most of the countries demonstrated improvement in $R E T$. Figure 1 clearly depicts the RET improvement in most of the sample countries. The improvement in $R E T$ was related to the forces of globalization. The movement of capital and corporations around the world has created a growing need for information about markets. It has also created an incentive for governments to streamline bureaucratic practices that hinder the free flow of capital (JLL 2008).

Similarly, the real estate sector has been experiencing significant movement toward greater internationalization. Evidence of this trend is reflected by the fact that in recent years there has been rapid growth in direct real estate investments and portfolio investments in the listed real estate securities (Topintzi et al. 2008; UNCTAD 2007). For example, statistics show that foreign real estate investments have accounted for $37 \%$ of the world's wealth (Brown, Matysiak 2000). Cross border investments account for $63 \%$ of total transaction volumes in Europe real estate markets (JLL 2007).
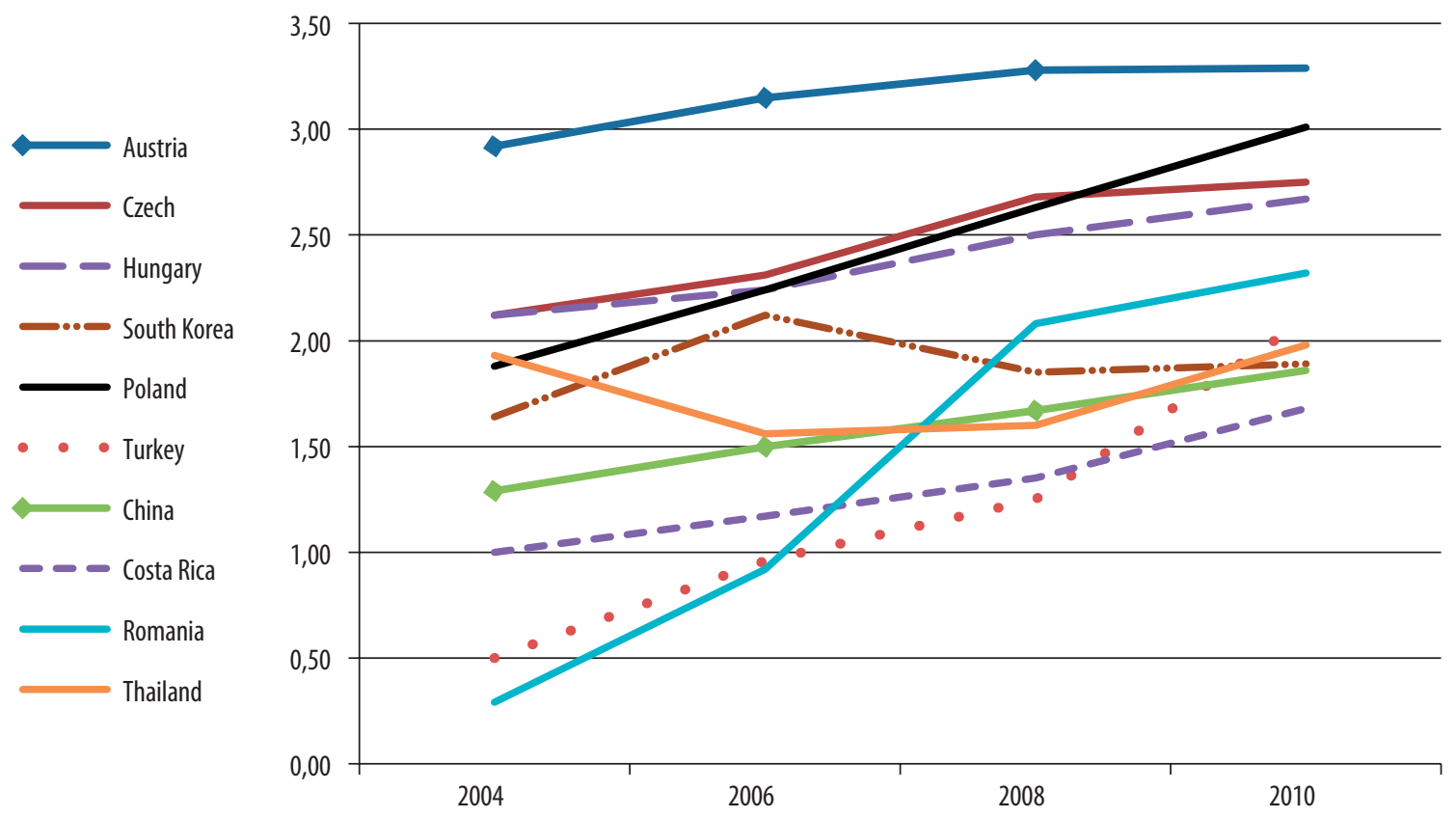

Fig. 1. Real estate transparency scores in some of the countries under study (JLL 2004, 2006, 2008, 2010) 
FDI flows into China's real estate market accounts for $10-15 \%$ of the total FDI from the middle of the 1990s to 2009 (He et al. 2009). Foreign real estate investment in Spain represents nearly $40 \%$ of total FDI inflows (Rodríguez, Bustillo 2010). More evidences on the recent surges of FREI in some countries under study can be seen in Appendix A.

\section{LITERATURE REVIEW}

Several researchers have studied the relationship between RET and FREI. The conclusions are contradictory: one set of researchers support a positive relationship between RET and FREI (e.g. Eichholtz et al. 2011; Falkenbach 2009; Schulte et al. 2005) and the second view argues that the relationship is negative or insignificant (e.g. JLL 2008, 2006). This section of paper intends to survey the arguments from some studies supporting each of these viewpoints.

JLL (2008) noted that uncertainty respecting foreign real estate investment laws could weaken investor confidence, caused confusion, negatively affected transparency and as a result decrease foreign direct investment in property sector. Similarly, JLL (2004) argued foreign real estate investors are not keen to invest in countries where domestic investors have easier access to information and therefore a competitive advantage, since the costs and risks of property transactions are high. JLL (2009a) argued improved transparency is important for investors because transparent markets allow for better risk management and the establishment of suitable risk premiums, the assessment of likely future investment returns through performance benchmarks. Transparent real estate markets also provide for enhanced decision-making through better information and the development of more robust and informed investment strategies and target allocations.

Eichholtz et al. (2011) found that international property companies mainly invest in countries that have relatively high scores on transparency. More specifically, they argued that the increased transparency reduces the information asymmetry problems (or reduce the information disadvantages) which it can improve foreign property companies' performance compared to those companies that operate locally. Furthermore, their results show that the institutional environment and the level of economic integration affect significantly on performance of international property companies. Eichholtz et al. (2001) stated that international investors always face a trade-off between diversification benefits and information costs. If information costs are so high that all potential benefits of international diversification are mitigated, international investment may then not occur. Dhar and Goetzmann (2006) documented that more complete information about the long-term performance of real estate asset class can help resolve uncertainty and affect institutional investors' demand for different types of properties. Geurts and Jaffe (1996) argued that imperfect information about the institutional framework leads to the home asset bias ${ }^{2}$. In other words, when information regarding the institutional framework is imperfect, the institutional risk of investing in a foreign country would be higher than international portfolio diversification benefits (e.g. reduction in unsystematic risk). He et al. (2009) provided evidences that foreign investors would favor those China's provinces with a more transparent real estate markets. More specifically, they argued that provinces that transfer their land use rights through a more open and transparent way would be attractive to foreign real estate investors and developers. Further, they found that foreign real estate investors avoid high labor cost provinces and high financing cost but significantly favor provinces with higher housing prices, developed land and housing commercialization, good governance, strong law enforcement and developed services. Falkenbach (2009) found that one of the important criteria for market selection in international real estate investments is availability of market information and performance benchmarks. In addition, their results indicated that the most important factors for market selection are expected return on property investments and safety of property rights and title. Triantafyllopoulos (2006) argued where there is no security of legal title and enforceability of property rights, domestic and international investors are not always willing to invest. Triantafyllopoulos further discussed that lack of information regarding real assets may cause a country to be ignored by real estate investors when they draw up their international investment strategies. Triantafyllopoulos also noted that when corruption dominates in property markets, the private marginal product of capital invested decrease because of the bribes that have to be paid, lowering the investment rate. As a result, participation of domestic and foreign investors in property market would decrease. In his analysis of internationalization

2 Home asset bias: Investors seem to bias their investments towards the domestic country, despite the prospects of significant gains to diversifying internationally (Geurts, Jaffe 1996). 
of real estate involvements in European markets, D'Arcy (2009) noted that considerable improvement in real estate transparency could contribute to the expansion of cross-border real estate capital flows in this region. Schulte et al. (2005) concluded that the more transparent the German real estate market, the more professional market participants have to behave correctly and the more interesting the market would become for foreign investors. In other words, transparent real estate markets provide as much information as possible for all market participants and therefore minimize the information advantages of other market participants. Lee (2001) showed that institutional real estate investors choose to invest in the most transparent, mature and least corrupt markets. He argued that if investors can become more informed of the institutional structures and business practices of overseas markets they are more likely to invest in those markets. Gelos and Wei (2002) found that there is relatively clear evidence that low transparency (or high opacity) tends to depress the level of international investments. In their study on Central and Eastern European economies, Adair et al. (2006) concluded those locations that possess transparent property market data have a competitive advantage and are more likely to attract investment funds. In his study on transparency in the Chinese' real estate development industry, Han (2005) found that more transparent a Chinese company, the more possible a successful joint venture with foreign investors.

With regard to aggregate FDI (including FDI in real estate), Drabek and Payne (2002) showed a nation that takes steps to increase the degree of transparency in its policies and institutions could expect significant increases in the level of foreign investment. Likewise, Seyoum and Manyak (2009) examined the role of public and private transparency in attracting inward FDI flows to developing countries. Their empirical analysis indicated that private and public sectors transparency have positive and significant effect on FDI inflows. Seyoum (2009) also found that foreign firms are willing to invest in developing countries with high levels of corporate transparency (e.g. adopting international financial reporting standards, increasing the level of disclosures to investors) because it increases their ability to accurately evaluate company performance. Egger and Winner (2003) found a positive impact of the viability of contracts and market size on FDI stock.

Apart from the above-mentioned works, some studies found (or argued) that RET does not have a significant impact on FREI. For example, JLL (2006) showed that investors' interest in less transparent markets like Japan, China and Mexico is rising rapidly. A report provided by JLL (2010) suggested that high level of transparency do not eliminate risks for investors or occupiers. JLL (2008) also showed that the association between the levels of transparency and the growth in cross-border real estate transaction volumes is not strong. For example, Japan and South Korea recorded solid increases in cross-border real estate transaction volumes in 2006-2007, in spite of minimal improvements in RET (JLL 2008). It is argued that rather than transparency enhancements being the key determinant of capital flows, property market fundamentals are the main driving force

Table 1. Review of the literature on real estate transparency and foreign investments

\begin{tabular}{|c|c|c|c|}
\hline Study & Subject of investigation & Approach & Relevant findings \\
\hline \multicolumn{4}{|l|}{ Qualitative Studies } \\
\hline JLL $(2004,2006,2008)$ & Real estate transparency & Reports & RET has positive impact on FREI. \\
\hline Triantafyllopoulos (2006) & $\begin{array}{l}\text { Market and institutional } \\
\text { constraints regarding real } \\
\text { estate investments }\end{array}$ & Conceptual paper & RET attracts real estate investors. \\
\hline Adair et al. (2006) & $\begin{array}{l}\text { Real estate transparency in } \\
\text { Central and Eastern Euro- } \\
\text { pean countries }\end{array}$ & Conceptual paper & $\begin{array}{l}\text { Those locations that possess trans- } \\
\text { parent property market data have a } \\
\text { competitive advantage and are more } \\
\text { likely to attract investment funds. }\end{array}$ \\
\hline D’Arcy (2009) & $\begin{array}{l}\text { The evolution of institutional } \\
\text { arrangements to support the } \\
\text { internationalization of real } \\
\text { estate involvements in Euro- } \\
\text { pean markets }\end{array}$ & Conceptual paper & $\begin{array}{l}\text { RET contributes to the expansion of } \\
\text { cross-border real estate capital flows. }\end{array}$ \\
\hline JLL $(2006,2008,2010)$ & Real Estate Transparency & Reports & $\begin{array}{l}\text { Not strong relationship between RET } \\
\text { and FREI. }\end{array}$ \\
\hline
\end{tabular}




\begin{tabular}{|c|c|c|c|}
\hline Study & Subject of investigation & Approach & Relevant findings \\
\hline Empirical Studies & & & \\
\hline
\end{tabular}

Eichholtz et al. (2011)

Seyoum and Manyak (2009)

He et al. (2009)

Falkenbach (2009)

Seyoum (2009)

Dhar and Goetzmann (2006)

Schulte et al. (2005)

Han (2005)

Egger and Winner (2005)

Egger and Winner (2003)

Gelos and Wei (2002)

Drabek and Payne (2002)

Lee (2001)

Eichholtz et al. (2001)

Geurts and Jaffe (1996) developing countries na's real estate sector ments parency on FDI real estate market incentive for FDI

\section{Contract risk and FDI} Asian region tion costs
Transparency, integration, and the cost of international real estate investments

Public and private sector transparency and FDI in

Determinants of FDI in Chi-

Market selection for international real estate invest-

Impact of corporate trans-

Institutional perspectives on real estate investing: the role of risk and uncertainty

Transparency in the German Descriptive analysis

Creating transparency in China's real estate sector

Evidence on corruption as an

Transparency and international investor behavior

Transparency and FDI

The risks of investing in the real estate markets of the

Trade-off between diversification benefits and informa-

Risk and international real estate investment

Performance of 848 international prop1996 through 2007

Cross sectional analysis - OLS regression (58 developing countries, 2003-2006)

Panel data regressions, using data from provinces of China (2000-2007)

Survey study ysis - OLS regression (118 countries, 2003-2006)

Survey study

Descriptive analysis

Panel data regression (73 countries,

Panel data regression, (50 countries, 1985-1997)

Regression analysis

2SLS regression (52 countries, 19921995)

Descriptive analysis of risk and return

Performance of 18 ing property companies (1984-1995)

Correlation analysis erty companies from

Cross sectional anal1995-1999) international operatreal estate market, the more professional market participants have to behave correctly and the more interesting the market would become for foreign investors.

More transparent a Chinese company, the more possible a successful joint venture with foreign investors.

Property companies mainly invest in

Positive impact of public and private sector transparency on FDI.

The significant determinants are: ancing cost, labor cost housing prices, land and housing commercialization, regional governance, law enforcement and developed services.

The important factors for market selection are Safety of property rights and title, expected return on property investments, describing institutional set-up and market maturity.

firms are willing to invest in developing countries with high levels of corporate transparency.

Complete information about the longterm performance of real estate asset class can help resolve uncertainty and affect institutional investors' demand for different types of properties.

Corruption is a stimulus for FDI.

Positive impact of the viability of contracts on FDI.

Low transparency depresses the level of international investments.

Positive relationship between transparency and FDI

Institutional real estate investors choose to invest in the most transparent, mature and least corrupt markets.

High information costs reduce international investments.

Imperfect information reduces foreign investments. 
behind cross-border transaction volumes. Regarding aggregate FDI, Egger and Winner (2005) found that corruption is a stimulus for FDI because corruption can be beneficial in circumventing regulatory and administrative restrictions. Since, real estate and property sector is seen to bribe officials most frequently (Transparency International 2008), therefore, we could expect that higher level of transparency in real estate sector may discourage FREI.

As the literature review reveals, findings of prior studies are contradictory and inconclusive. Given past empirical research, a positive, negative or insignificant coefficient is expected for the $R E T$ variable. Table 1 presents a summary of the most important findings of the relevant qualitative and empirical studies.

\section{DATA AND VARIABLES}

We use observations from 32 countries $^{3}$ covering 2004, 2006, 2008 and 2010. Included are all countries for which data on RET and FREI is obtainable. The relationship between RET and FREI is our main concern.

Information on countries' RET is taken from the Jones Lang LaSalle/LaSalle (JLL) Investment Management Real Estate Transparency Index. JLL introduced the first Global Real Estate Transparency Index in 1999 in order to characterize the relative transparency of key global real estate markets. It should be noted that JLL provides global real estate transparency index every two years. JLL defines real estate transparency "as any open and clearly organized real estate market operating in a legal and regulatory framework that is characterized by a consistent approach to the enforcement of rules and regulations and that respects private property rights". In 2006, they added a new dimension to this definition: "the ethical and professional standards of private sector advisors, agents and brokers who are licensed to conduct business in each country" (JLL 2006: 3). On the other hand, an opaque real estate market is a market that has the following characteristics: absence of financial benchmarks, lack of historical or current market statistics on supply, demand or rent; financial statements of listed vehicles that are neither detailed nor standardized according to generally accepted accounting principles (GAAP)/ international accounting standards (IAS); real estate tax procedures and building and zoning codes

\footnotetext{
3 The country sample can be found in the Appendix B.
}

that are not published or are selectively enforced; situations where local assistance or under-thetable payments are required to navigate the investment/development/management process; lack of title records or title insurance; environments in which government or public utilities acquire private property on short notice, introducing risk that owners will not be fairly compensated (JLL 2004: 2). The index is calculated by using a neutral weighting. The scores range between 1 and 5 . A country with a perfect 1 would be the country with the highest level of transparency. A country with a 5 would be a country with total opacity. In order to facilitate the interpretation of this index, we have reversed the scores (1: total opacity and 5: the highest level of transparency).

The data on real FDI inflows to real estate sector (FREI) is obtained from a wide range of sources. The complete FREI data sources can be found in Appendix B. FREI includes selling or buying real estate, renting real estate, providing other real estate services such as appraising real estate by foreign individuals and enterprises, whenever these foreigners do not maintain a permanent residence in the host country. The definition of FREI is almost identical for most of the sample countries. It is measured in millions of US dollars. Following Kolstad and Villanger (2008) we have adjusted for country size by dividing FREI by its population.

Besides the RET, we observe that some variables show the persistent influence on FREI. Thus, for the purpose of specification of the econometric work, several explanatory variables, besides $R E T$, are added to our empirical model. Above all, market size in host country is one of the important factors in explaining FREI. UNCTAD (2003) emphasizes that some of foreign investors invest in developing countries mainly to introduce their real estate activities into the host countries. Foreign investors in a country's real estate pay close attention to the size of local market for marketing their final goods which is real estate. A very common proxy to measure the capacity of local market to buy the final product is the real income per capita. A higher GDP per capita of residents of host country indicates a higher effective demand for the kinds of goods and services produced by foreign investors. It also captures potential economies of large-scale production such as in real estate sector. For example, He et al. (2009) argued that a higher level of GDP per capita in China would create a higher demand for real estate properties, therefore attracting more FDI in the real estate industry (as more local demands and larger market size 
would create higher revenues for foreign real estate investors). Rodríguez and Bustillo (2010) also showed that GDP per capita (as the purchasing power of the consumer of real estate services) has the strongest effect on foreign real estate investments. Falkenbach (2009) documented that market size is an important factor in attracting foreign investors to the host country's real estate market (because market size reflects availability of investment possibilities). Based on previous studies, it is hypothesized that market size is a significant determinant of FREI. Following Chakrabarti (2001) and Kolstad and Villanger (2008), GDP per capita is used as a proxy for market size in the present study. The data on the real GDP per capita come from World Bank's World Development Indicators.

In prior studies, infrastructure was recognized as one of the main determinants of FREI. For example, Ramasamy and Yeung (2010) showed a positive and significant result proving that countries that have an established infrastructure would attract greater amounts of FDI in service sectors (including real estate). Renaud (2010) argued that infrastructure development was one of the major factors that attract foreign investors in Dubai's real estate sector. Chin et al. (2006) also found that level of public infrastructure is one of the important factors for property investors in Southeast Asian cities' real estate markets. Lall et al. (2003) showed that the level of development of the physical infrastructure had a positive impact on the level of long-term foreign direct investment in the Caribbean and Latin America regions. UNCTAD (2004) stated the upgrading of the physical infrastructure (especially in information and communication technology) was required by most foreign investors in order to perform needed services. In our study, internet user (per 100 people) is used as a proxy for country's infrastructure. Information on this variable is taken from the World Bank's World Development Indicators. Internet can increase productivity of foreign investors in several ways. Internet can reduce prices by lowering international communication and searching costs. It also makes entry to markets easier by reducing the entry costs. Both reductions in search and entry costs will increase competition and we observe increasing productivity in competitive markets. In addition, internet can reduce the cost of holding inventories through direct contact of large suppliers with customer, cutting the costs of working with retailers. This latter issue also increases productivity. Finally, the transparency and flow of information among markets is higher when a country enjoys a higher degree of internet penetration (for an empirical investigation of effect of internet on FDI see Choi 2003).

Another determinant of FREI is the financing costs in the host countries. It is because foreign investors in service sectors (including real estate) rely on the host country's financial systems to raise the capital that is required for their investment (Ramasamy, Yeung 2010). Therefore, a high interest rate could negatively influence the extent of FDI inflow because a large amount of funds could be raised by foreign investors from the financial system of the host countries. This argument is consistent with a number of previous studies. He et al. (2009) found that foreign investors in China's real estate industry avoid provinces with high financing cost (or lower value for loan). This means that foreign investors favor locations in which foreign investors are easy to borrow money from commercial banks. In their study on determinants of FREI in Spain, Rodríguez and Bustillo (2010) also found that FREI is negatively related to the long-term interest rate. With regard to aggregate FDI, Zhao (2003) found that the relatively high costs of capital borrowing in China inhibited the flow of FDI. Based on the above discussion, one would expect that the lower financing cost in the host countries would attract greater amount of FREI. The data on the annual lending rates (proxy for financing cost) come from International Monetary Fund (IMF), International Financial Statistics.

Furthermore, existing literature present evidences that FDI inflows to other sectors has a significant effect on FREI. It is expected that as the foreign investors (in manufacturing and services sector) expand their operations in the host country, their demand for investments in real estate in that host country will increase as well. Moshirian and Pham (2000) found that U.S. FDI in real estate abroad is positively correlated with U.S. FDI in manufacturing and banking abroad. In other words, their results implied that expansion of U.S. investment in the form of manufacturing and banking contributes to U.S. investment in real estate abroad. Similarly, Hines (2001) documented that as industrial and financial firms expand their operations overseas, they require properties (industrial, commercial, residential real estate) by acquisition or lease that fit their particular corporate needs (such as carrying on their international business and house their employees). He et al. (2009) also argued that foreign investors in real estate industry follow their customers (such as international business personnel) to the host 
Table 2. Description of variables

\begin{tabular}{llll}
\hline Variable & Description & Source & Expected sign \\
\hline FREI & Aggregate FDI inflows to real estate sector & Various sources (see Appendix B) & Jones Lang LaSalle \\
RET & Real estate transparency & Worldwide Governance Indicators of & + or - \\
CC & Control of corruption (Transparency) & the World Bank & + \\
& & World Bank's World Development & + \\
GDPcap & GDP per capita (market size) & Indicators & + \\
& & World Bank's World Development & + \\
INFRAS & Internet user - per 1000 people (Infrastructure) & Indicators \\
ROAD & Density of road network (Infrastructure) & Global Market Information Databases & + \\
FINC & Annual lending rate (Financing costs) & International Monetary Fund (IMF), & - \\
& & International Financial Statistics & + \\
FDI & Foreign direct investments in other sector & World Bank's World Development & Indicators \\
& & Global Market Information Databases & + \\
\hline
\end{tabular}

economies. In particular, they found that foreign investors were attracted to China's real estate industry due to the demand created by foreign enterprises. Likewise, Bardhan and Kroll (2007) noted that major U.S. real estate service firms and residential real estate brokerage firms follow U.S. multinational companies in developing countries in order to provide residential real estate services for expatriate population. He and Zhu (2010) found that foreign direct investors in real estate sector favored Chinese cities with more international tourists and more foreign investments. It is because both international tourists and foreign managers in foreign companies prefer to stay in hotels or apartments that provide offices (or easy access to them), accommodation, and eating facilities meeting Western standards. Information on this variable is taken from World Bank's World Development Indicators.

Finally, a number of researchers found that heightening property prices in the host countries attract foreign investment in real estate sector (He et al. 2009; Zhu et al. 2006). For example, in their financial model for foreign real estate investment in Spain, Rodríguez and Bustillo (2010) found that there is a long-run and positive relationship between expectations of increasing prices for real estate assets and foreign real estate investments in Spain. In particular, they argued that Spain is attractive for real estate investment because the future return of the present investment is expected to be high. Similarly, He et al. (2009) showed that the heightening housing prices significantly stimulate the inflow of FDI in China's real estate industry. They argued that foreign investors in real estate lean towards those (China) provinces with higher average housing prices. JLL (2009b) stated that potential for capital growth is one of the main criteria for long term investors in Middle East and North Africa (MENA) countries' real estate sectors. As a proxy for property prices, we use housing price index $(2010=100)$ provided by the Global Market Information Databases (GMID). A summary of variables used in the present study is given in Table 2. The descriptive statistics of variables are given in Appendix C.

\section{METHODOLOGY AND RESULTS}

The aim of this study is to investigate the relationship between RET and FREI after controlling for some other relevant variables. Given the earlier discussion, the following panel data model is specified:

$$
\begin{aligned}
& \ln F R E I_{i t}=\beta 0+\beta 1 \ln R E T_{i t}+\beta 2 \ln \text { GDPcap }_{i t}+ \\
& \beta 3 \ln I N F R A S_{i t}+\beta 4 \ln F I N C_{i t}+\beta 5 \ln F D I_{i t}+ \\
& \beta 6 \ln P P R I C_{i t}+v_{i}+e_{i t} \text {, }
\end{aligned}
$$

where: $F R E I_{i t}$ stands for FDI in real estate in country $i$ and period $t ; R E T_{i t}$ stands for real estate transparency in country $i$ and period $t$; GDPcap G $_{i t}$ represents the market size in country $i$ and period $t ; I N F R A S_{i t}$ denotes the level of infrastructure in country $i$ and period $t$; FINC $i t$ is the financing costs for country $i$ and period $t ; F D I_{\text {it }}$ represents foreign investments in other sectors in country $i$ and period $t$; PPRIC $C_{i t}$ denotes the property price for country $i$ and period $t_{i}, v_{i}$ is country fixed-effect and $e_{i t}$ is an error term. We use the logarithm for all variables. There are three main reasons that we use logarithm for variables. First, positive vari- 
able often are heteroskedastic or skewed; taking the logarithm can mitigate, if not eliminate, both problems. Second, taking logarithm usually narrows the range of the variable. This makes estimates less sensitive to outlying observations on the dependent or independent variables. Third, using logarithm leads to coefficients with appealing interpretation, and we can be ignorant about the units of measurement of variables appearing in logarithmic form because the slope coefficients are invariant to rescaling (Wooldridge 2009: 191).

In the present study, panel data regressions are applied to estimate the relationships between the explanatory variables and FREI. We employ two different econometric techniques, a country fixed-effect model $^{4}$ and the generalized method of moments (GMM) estimator. Generally, fixed-effect estimator is used to capture unobserved country specific effects and it also produces consistent estimates. In other words, the panel data analysis with country fixed-effect approach allows us to distinguish more systematically between the effects of RET and other variables on FREI over time as well as across countries.

The results of the equation (1) using fixed-effect estimation approach are reported in column 1 of Table 3 . The results suggest that there is no significant relationship between RET and FREI. The finding indicates that a rise in transparency in real estate markets do not lead to a significant increase in foreign investments in real estate in the sample countries. Thus, $R E T$ is not a critical factor in determining the level of FREI. This result does not provide support for previous studies (e.g. Schulte et al. 2005; Triantafyllopoulos 2006). However, this outcome is consistent with JLL (2008) which found that the relationship between $R E T$ and FREI is not strong. One reason for this result can be explained by Egger and Winner (2005)'s findings. They found that corruption and lack of transparency are stimulus for foreign investments because these factors can be beneficial in circumventing regulatory and administrative restrictions.

\footnotetext{
4 Two important panel models that consider the unobserved effects (or fixed effects) are the fixed-effect and the randomeffect methods. The fixed-effect estimator uses a transformation to remove the unobserved effect prior to estimation. Any time constant explanatory variables are removed along with the unobserved effect. The random-effects estimator is applicable when we think the unobserved effect is uncorrelated with all the explanatory variables (Wooldridge 2009). In order to determine which model is preferred for the equation estimation, a Hausman test is used. The Hausman Chi-square statistic is significant at the $5 \%$ level indicating that the random-effect model is inconsistent and fixed-effect model is preferred to estimate the equation (1) in the present study.
}

Second, the role of RET may be lessen by other location factors such as property prices and market size. Third, high level of RET may discourage those foreign speculators who seek local opportunities in the presence of asymmetric information. Finally, it can be argued that sometimes investors locate their real estate investments in low transparency countries because they expect higher returns for that investment, a factor that could explain the lack of influence of transparency over FREI.

Moreover, our results indicate that GDP per capita (proxy for market size) is positive and significant suggesting that larger market size attract greater amount of FREI. This result is consistent with He et al. (2009) who found that GDP per capita is a significant determinant of FREI. Furthermore, the findings provide evidence that FDI is positively and statistically associated with FREI, indicated by an estimated coefficient that is significant at the $1 \%$ level. In other words, countries with higher level of FDI in other sectors attract greater amounts of FREI. This argument is in accordance with He and Zhu (2010). The coefficient for property prices (PPRIC) has positive sign, meaning that an increase in this factor is positively associated with higher FREI. This result is consistent with Rodríguez and Bustillo (2010) and He et al. (2009) who found that property price is one of the major determinants of FREI. Finally, INFRAS and FINC have the expected signs but not significant.

So far, it is assumed that the RET and the control variables are exogenous (variables that are not correlated with the residuals). However, in some cases this is obviously an unrealistic assumption. For example, greater amount of foreign investments in real estate contribute to economic development and higher level of GDP (e.g. Ning, Yu 2009). Likewise, higher number of international participants in host countries' real estate market may intensify the pressure on transparency standards. The standard approach in cases where right-hand side variables are correlated with the residuals (or endogeneity problem) is to estimate the equation using instrumental variables regression, particularly the GMM.

Another econometric problem is that time-series regression analysis may involve autocorrelation of the disturbances or serial correlation. We can solve this econometric problem (autocorrelation) by including the lagged dependent variable on the right hand side of the regression equations (Busse, Hefeker 2007). In doing so, by using lagged FREI in the equation, the econometric specification will be changed to a dynamic panel. A usual 
method for dynamic panels is the GMM estimator. Arellano and Bond (1991) and Arellano and Bover (1995) suggested first-differencing the model to eliminate the unobserved effects and then using valid instruments to deal with the problem of the new error term being correlated with the lagged dependent variable.

A drawback of the difference GMM is that when first differences are taken, time-invariant variables are removed. Therefore, the first difference GMM does not use the cross-sectional information reflected in the differences between countries. Another disadvantage of first difference GMM is that lagged levels are often poor instruments for the equation in difference, which can lead to poor precision in the estimators. To mitigate this problem, a new estimator is used, namely, the system GMM, developed by Arellano and Bover (1995) and Blundell and Bond (1998). This estimator is based on an augmented system that includes the regression in differences and in addition to the regression in the levels with lagged differences as instruments (Bajo-Rubio et al. 2010). Thus, we use the system GMM estimator to investigate the relationships between explanatory variables and FREI.

The use of valid instruments is required in order to control for the potential endogeneity of the other explanatory variables. The consistency of the GMM estimator depends on the validity of the instruments, which is examined by means of two specifications tests (Arellano, Bond 1991). First, the Sargan test statistic of over-identifying restrictions (that tests the hypothesis that the instrument variables are not correlated with the residuals). The validity of the instrument variables should not be rejected by Sargan test. Second, we need to test the null hypothesis of no second-order correlation in the residuals (Bajo-Rubio et al. 2010). In order to have consistent GMM estimators, the null hypothesis of no second-order serial correlation should not be rejected.

Column 2 of Table 3 presents the results of the GMM system regression. Similar to the fixedeffect regression, we find that $R E T$ is not a major determinant of FREI, as its coefficient is not statistically significant. The results for GDPcap and $F D I$ are in line with those of the fixed-effect panel regression, as these two variables are significant and have an identical positive sign. In addition, the result for PPRIC indicates that this variable is positively associated with FREI in a dynamic panel setting. On the other hand, FINC and INFRAS are not significant determinants of FREI in sample countries. The Sargan test $(p$-value $=$ 0.7167) shows that the applied instruments are valid (see Table 3). The residuals also do not exhibit second-order serial correlation, as shown by an insignificant $p$-value of AR (2). Thus, neither of the test statistics leads us to reject the assumption of consistency of the GMM estimator.

Table 3. Regression results

\begin{tabular}{|c|c|c|c|}
\hline \multicolumn{4}{|c|}{ Dependent variable: $\ln$ FREI } \\
\hline Explanatory variables & $\begin{array}{l}(1) \\
\text { Fixed-effect }\end{array}$ & $\begin{array}{l}\text { (2) } \\
\text { GMM }\end{array}$ & $\begin{array}{l}\text { (3) } \\
\text { GMM }\end{array}$ \\
\hline RET & $\begin{array}{l}-0.6529 \\
(-1.5816)\end{array}$ & $\begin{array}{l}-0.5334 \\
(-1.0696)\end{array}$ & $\begin{array}{l}-0.8886 \\
(-1.3698)\end{array}$ \\
\hline $\operatorname{lnGDPcap}$ & $\begin{array}{l}0.2956^{*} \\
(1.6831)\end{array}$ & $\begin{array}{l}2.8185^{*} \\
(1.9544)\end{array}$ & $\begin{array}{l}0.4790 * * \\
(2.6205)\end{array}$ \\
\hline lnINFRAS & $\begin{array}{l}0.0915 \\
(0.2945)\end{array}$ & $\begin{array}{l}0.2190 \\
(0.4111)\end{array}$ & $\begin{array}{l}0.1854 \\
(0.6093)\end{array}$ \\
\hline FINC & $\begin{array}{l}-0.0109 \\
(-0.1912)\end{array}$ & $\begin{array}{l}-0.0889 \\
(-0.8416)\end{array}$ & $\begin{array}{l}-0.1570 \\
(-0.5730)\end{array}$ \\
\hline $\operatorname{lnFDI}$ & $\begin{array}{l}0.3899 * * * \\
(3.9933)\end{array}$ & $\begin{array}{l}1.0036^{* *} \\
(2.7223)\end{array}$ & $\begin{array}{c}0.3214^{* * *} \\
(3.1800)\end{array}$ \\
\hline $\operatorname{lnPPRIC}$ & $\begin{array}{l}0.3331^{*} \\
(1.7125)\end{array}$ & $\begin{array}{l}1.9425^{*} \\
(1.9564)\end{array}$ & $\begin{array}{l}0.1767 \\
(1.4119)\end{array}$ \\
\hline RET $\times \operatorname{lnGDPcap}$ & - & - & $\begin{array}{l}0.3928 * * \\
(2.3262)\end{array}$ \\
\hline Adjusted R-Square & 0.3007 & - & - \\
\hline \multicolumn{4}{|l|}{ Test p-values } \\
\hline Sargan Test & - & 0.7167 & 0.6502 \\
\hline $\mathrm{AR}(2)$ & - & 0.3520 & 0.3301 \\
\hline
\end{tabular}

Notes: Significant at: ${ }^{*} 10, * * 5$ and $* * * 1 \%$; t-values reported in parentheses. 
Therefore, the combined evidence (fixed-effect and the GMM regressions) suggests that RET does not contribute to the higher level of FREI in the sample countries.

Finally, we examine whether $R E T$ interacts with per capita income (GDPcap) to affect FREI. In other words, we test jointly whether $R E T$ and GDPcap variables affect FREI by themselves or through the interaction term. Such specification is adopted in model (2). This specification is motivated by findings of Kolstad and Villager (2008) who found that political economy determinants of FDI impact groups of countries in term of income differently.

$$
\begin{aligned}
& \ln \text { FREI }_{i t}=\beta 0+\beta 1 \ln R E T_{i t}+\beta 2 \ln \text { SDPcap }_{i t}+ \\
& \beta 3 \ln R E T_{i t} \times \ln \text { SPPap }_{i t}+\beta 4 \ln I N F R A S_{i t}+\beta 5 \\
& \ln \text { FINC }_{i t}+\beta 6 \ln F D I_{i t}+\beta 7 \ln P P R I C_{i t}+v_{i}+e_{i t}
\end{aligned}
$$

As can be seen in Column 3 of Table 3, the GMM regression results show that the coefficient for $R E T$ is negative and insignificant, while the interaction term $(\ln R E T \times \ln G D P c a p)$ is positive suggesting the higher the level of income in the host country, the higher the effect of RET on FREI. It means that RET can brings more FREI in richer countries.

Figure 2 shows the RET and FREI trends in the same graph for some countries under study. As can be seen, the association is not clearly positive or negative. The inconclusive relationship confirms our findings which there is not a significant relationship between RET and FREI.

Finally, we run more regressions to ensure the robustness of our findings. We consider different proxy for $R E T$ and infrastructure. The alternative proxy for $R E T$ is control of corruption $(C C)$ which is provided by the Worldwide Governance Indicators of the World Bank. The score for this indicator ranges from -2.5 (worst performance) to 2.5 (best performance). $C C$ captures perceptions of the extent to which public power is exercised for private gain, including both petty and grand forms of corruption, as well as "capture" of the state by elites and private interests. The alternative proxy for physical infrastructure is density of road network $(R O A D)$. Density of road network is total length, in kilometres, of motorways, highways/main/national roads, secondary/regional roads and other roads, divided by the area of the country in sq $\mathrm{km}$. The data for density of road network are obtained from Global Market Information Databases. As can be seen from Appendix D, the results are unchanged and robust to the inclusion of the alternative proxy for RET and infrastructure. The coefficients for $C C$ and $R O A D$ are statistically insignificant.

\section{CONCLUSIONS}

Several researchers have studied the relationship between real estate transparency (RET) and foreign real estate investments (FREI). The conclusions are contradictory: one set of researchers support a positive relationship between $R E T$ and FREI; and the second view argue that the relationship is insignificant or negative. While there has been a series of conceptual and cross-sectional studies published in this area, very few empirical works have examined the effects of RET on FREI by applying a panel data approach.

In this study, we empirically investigate the relationship between RET and FREI for 32 countries covering 2004, 2006, 2008 and 2010. Applying fixedeffect and GMM estimation approaches, the results show that higher level of RET could not contribute to the expansion of FREI in the sample countries. However, we find that the effect of RET on FREI is dependent on its interaction with the level of income. Moreover, our results indicate that foreign real estate investors favor those countries with larger market size, higher level of foreign investments in other sectors and higher property prices.

While higher level of RET appears not to be associated with more FREI, our results, of course, should not be interpreted as support for opaque real estate markets. In contrast, improvements in $R E T$ should be considered by policymakers because transparent markets can eliminate the speculations in real estate markets (which has several negative consequences for national economies such as property bubble and financial crisis). Moreover, in order to attract higher level of FREI, policymakers should enhance real estate transparency along the economic development.

Ultimately, the results of the study should be considered in light of its limitations, which also point to some issues for future research. First, the present study only considered the aggregate FREI for analysis. For future research, it may be useful to examine the relationship between $R E T$ and FREI by using disaggregate data for various types of properties such as residential, commercial and industrial. Second, using just 32 countries for 4 years is one of the study's limitations. Given the data constraints, results should be viewed with caution and hence, data from more countries and longer period is needed to fully investigate the relationship between $R E T$ and FREI. 


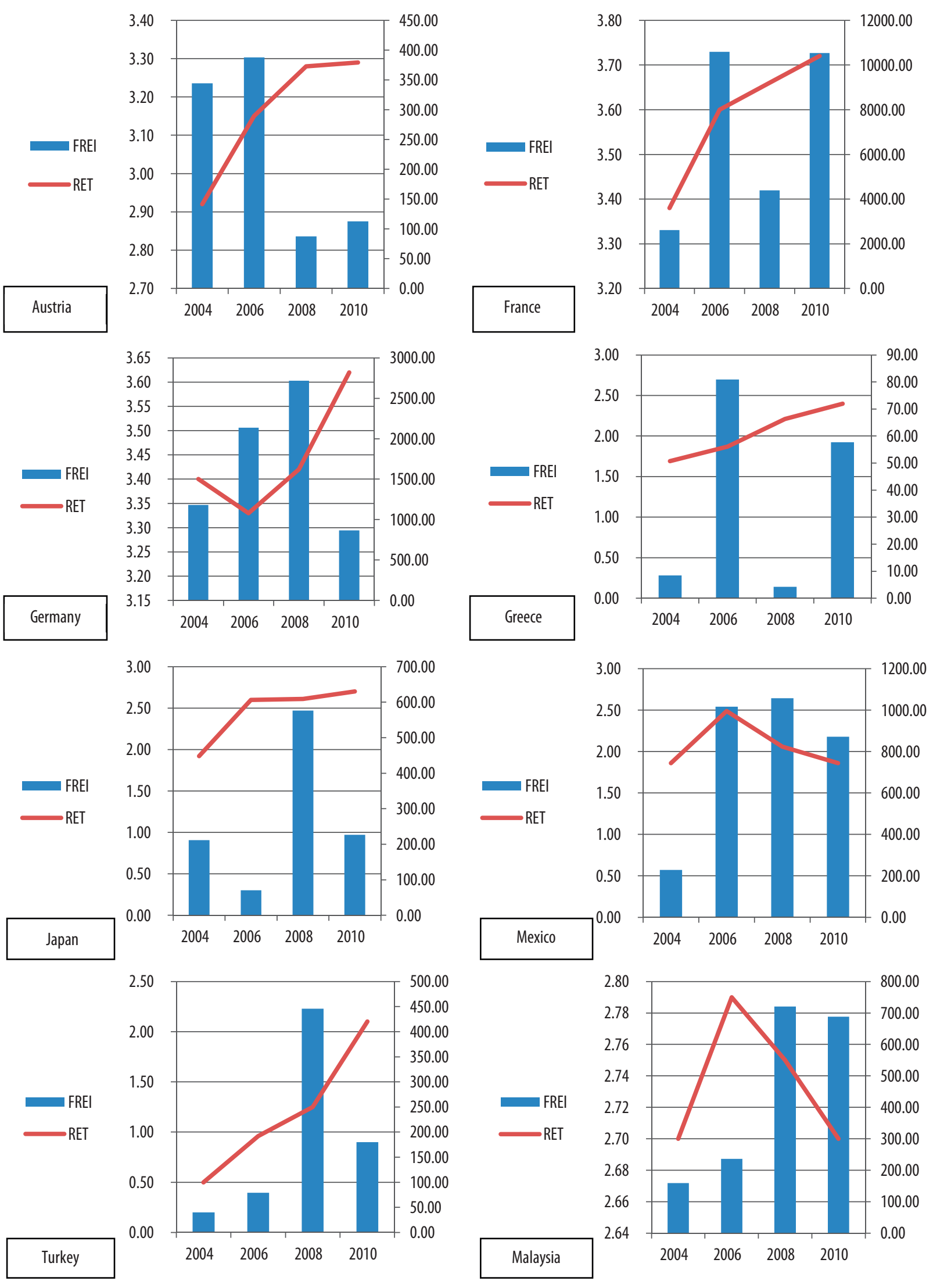

Fig. 2. The association between real estate transparency (RET) and foreign investments in real estate (FREI) 


\section{REFERENCES}

Adair, A.; Allen, S.; Berry, J.; McGreal, S. 2006. Central and Eastern European property investment markets: issues of data and transparency, Journal of Property Investment \& Finance 24(3): 211-220. http://dx.doi. org/10.1108/14635780610659928

Arellano, M.; Bond, S. 1991. Some tests of specification for panel data: Monte Carlo evidence and an application to employment equations, Review of Economic Studies 58(2): 277-297. http://dx.doi. org/10.2307/2297968

Arellano, M.; Bover, O. 1995. Another look at the instrumental variable estimation of error-components models, Journal of Econometrics 68(1): 29-51. http:// dx.doi.org/10.1016/0304-4076(94)01642-D

Bajo-Rubio, O.; Díaz-Mora, C.; Díaz-Roldán, C. 2010. Foreign direct investment and regional growth: an analysis of the Spanish case, Regional Studies 44(3): 373382. http://dx.doi.org/10.1080/00343400802508844

Baltagi, B. H. 2005. Econometric analysis of panel data. 3 ed. England: Willey.

Bardhan, A.; Kroll, C. A. 2007. Globalization and the real estate industry: issues, implications, opportunities, in Sloan industry studies annual conference, April 2007, Cambridge.

Blundell, R.; Bond, S. 1998. Initial conditions and moment restrictions in dynamic panel data models, Journal of Econometrics 87(1): 115-143. http://dx.doi. org/10.1016/S0304-4076(98)00009-8

Brown, G. R.; Matysiak, G. A. 2000. Real estate investment: a capital market approach. Singapore: Financial Times Prentice Hall.

Busse, M.; Hefeker, C. 2007. Political risk, institutions and foreign direct investment, European Journal of Political Economy 23(2): 397-415. http://dx.doi. org/10.1016/j.ejpoleco.2006.02.003

Chakrabarti, A. 2001. The determinants of foreign direct investment: sensitivity analyses of cross-country regressions, KYKLOS 54(1): 89-114. http://dx.doi. org/10.1111/1467-6435.00142

Chin,W.; Dent, P.; Roberts, C. 2006. An exploratory analysis of barriers to investment and market maturity in Southeast Asian cities, Journal of Real Estate Portfolio Management 12(1): 49-58.

Choi, C. 2003. Does the Internet stimulate inward foreign direct investment?, Journal of Policy Modeling 25(4): 319-326. http://dx.doi.org/10.1016/S01618938(02)00202-8

Cordero, J.; Paus, E. 2008. Foreign investment and economic development in Costa Rica: the unrealized potential, Working Group on Development and Environment in the Americas: Discussion paper Number 13, April 2008.

D'Arcy, E. 2009. The evolution of institutional arrangements to support the internationalization of real estate involvements: some evidence from Europe, Journal of European Real Estate Research 2(3): 280-293. http://dx.doi.org/10.1108/17539260911000006

Dhar, R.; Goetzmann, W. N. 2006. Institutional perspectives on real estate investing: the role of risk and uncertainty, Journal of Portfolio Management 32: 106-116. http://dx.doi.org/10.3905/jpm.2006.644202
Drabek, Z.; Payne, W. 2002. The impact of transparency on foreign direct investment, Journal of Economic Integration 17(4): 777-810. http://dx.doi.org/10.11130/ jei.2002.17.4.777

Egger, P.; Winner, H. 2003. Does contract risk impede foreign direct investment?, Swiss Journal of Economics and Statistics 139: 155-172.

Egger, P.; Winner, H. 2005. Evidence on corruption as an incentive for foreign direct investment, European Journal of Political Economy 21: 932-952. http:// dx.doi.org/10.1016/j.ejpoleco.2005.01.002

Eichholtz, P. M. A.; Gugler, N.; Kok, N. 2011. Transparency, integration, and the cost of international real estate investments, Journal of Real Estate Finance and Economics 43: 152-173. http://dx.doi. org/10.1007/s11146-010-9244-5

Eichholtz, P. M. A.; Koedijk, K.; Schweitzer, M. 2001. Global property investment and the costs of international diversification, Journal of International Money and Finance 20(3): 349-366. http://dx.doi. org/10.1016/S0261-5606(01)00004-3

Falkenbach, H. 2009. Market selection for international real estate investments, International Journal of Strategic Property Management 13(4): 299-308. http://dx.doi.org/10.3846/1648-715X.2009.13.299-308

Gelos, R. G.; Wei, S. J. 2002. Transparency and international investor behavior, Working Paper 9260, National Bureau of Economic Research, October 2002.

Geurts, T. G.; Jaffe, A. J. 1996. Risk and real estate investment: an international perspective, Journal of Real Estate Research 11(2): 117-130.

Han, F. 2005. Creating transparency in the Chinese real estate development industry: a case study: Master thesis. Massachusetts Institute of Technology.

He, C.; Wang, J.; Cheng, S. 2009. What attracts foreign direct investment in China's real estate development?, Annals of Regional Science 46(2): 267-293. http://dx.doi.org/10.1007/s00168-009-0341-4

He, C.; Zhu, Y. 2010. Real estate FDI in Chinese cities: local market conditions and regional institutions, Eurasian Geography and Economics 51(3): 360-384. http://dx.doi.org/10.2747/1539-7216.51.3.360

Hines, M. A. 2001. Investing in international real estate. USA: Greenwood Publishing Group.

JLL 2004. Real estate transparency index 2004. Jones Lang LaSalle (JLL).

JLL 2006. Real estate transparency index 2006. Jones Lang LaSalle (JLL).

JLL 2007. On point. European capital markets bulletin 2007 and views of 2008. Jones Lang LaSalle (JLL).

JLL 2008. Real estate transparency index 2008. Jones Lang LaSalle (JLL).

JLL 2009a. On point. Dubai city profile, October 2009. Jones Lang LaSalle (JLL).

JLL 2009b. Pules, MENA house view, September 2009. Jones Lang LaSalle (JLL).

JLL 2010. Real estate transparency index 2010. Jones Lang LaSalle (JLL).

Lall, P.; Norman, D. W.; Featherstone, A. M. 2003. Determinants of US direct foreign investment in the Caribbean, Applied Economics 35(13): 1485-1496. http://dx.doi.org/10.1080/0003684032000100382 
Lee, S. L. 2001. The risks of investing in the real estate markets of the Asian region, Working Paper, University of Reading.

Kolstad, I.; Villanger, E. 2008. Determinants of foreign direct investment in services, European Journal of Political Economy 24(2): 518-533. http://dx.doi. org/10.1016/j.ejpoleco.2007.09.001

Moshirian, F.; Pham, T. 2000. Determinants of US investment in real estate abroad, Journal of Multinational Financial Management 10(1): 63-72. http:// dx.doi.org/10.1016/S1042-444X(99)00019-5

Ning, J.; Yu, B. 2009. The analysis on FDI's technology spillover based on industrial relationship: China's real estate industry as an example, in Proceedings of 2009 International Conference on Construction \& Real Estate Management, 05-06 November 2009, Beijing, China, vols 1 and 2, 1266-1269.

Ramasamy, B.; Yeung, M. 2010. The determinants of foreign direct investment in services, World Economy 33(4): 573-596. http://dx.doi.org/10.1111/j.14679701.2009.01256.x

Renaud, B. 2010. Dubai's real estate boom and bust of 2002-2008: dynamics and policy responses, Housing Finance International 2010(Summer): 6-17.

Rodríguez, C.; Bustillo, R. 2010. Modeling foreign real estate investment: the Spanish case, Journal of Real Estate Finance and Economics 41(3): 354-367. http:// dx.doi.org/10.1007/s11146-008-9164-9

Schulte, K. W.; Rottke, N.; Pitschke, C. 2005. Transparency in the German real estate market, Journal of Property Investment \& Finance 23(1): 90-108. http:// dx.doi.org/10.1108/14635780510575111

Seyoum, B. 2009. An empirical analysis of the impact of corporate transparency on foreign direct investment, Multinational Business Review 17(3): 29-48. http:// dx.doi.org/10.1108/1525383X200900016
Seyoum, B.; Manyak, T. G. 2009. The impact of public and private sector transparency on foreign direct investment in developing countries, Critical Perspectives on International Business 5(3): 187-206. http:// dx.doi.org/10.1108/17422040910974686

Topintzi, E.; Chin, H.; Hobbs, P. 2008. Moving towards a global real estate index, Journal of Property Investment \& Finance 26(4): 286-303. http://dx.doi. org/10.1108/14635780810886654

Transparency International 2008. Annual Report 2008. Available at: http://www.transparency.org/publications/annual_report

Triantafyllopoulos, N. 2006. Public sector transparency and tourism real estate investments in Greece, Regional and Sectoral Economic Studies 6(2): 57-72.

UNCTAD 2003. World investment report 2003: FDI policies for development, national and international perspective. United Nations Conference on Trade and Development (UNCTAD), New York.

UNCTAD 2004. World investment report 2004: the shift towards services. United Nations Conference on Trade and Development (UNCTAD), Geneva.

UNCTAD 2007. World investment report 2007: transnational corporations, extractive industries and development. United Nations Conference on Trade and Development (UNCTAD), Geneva.

Wooldridge, J. M. 2009. Introductory econometrics: a modern approach. 4th ed. Canada: South-Western, Cengage Learning.

Zhao, H. 2003. Country factor differentials as determinants of FDI flow to China, Thunderbird International Business Review 45(2): 149-169. http://dx.doi. org/10.1002/tie.10067

Zhu, J.; Sim, L.; Zhang, X. 2006. Global real estate investments and local cultural capital in the making of Shanghai's new office locations, Habitat International 30(3): 462-481. http://dx.doi.org/10.1016/j. habitatint.2004.12.003

\section{APPENDIX A}

FDI in Real Estate (FREI) and its proportion of GDP from Real Estate, Renting and Business Activities (GDPrrb) (millions of US dollars) (Various sources, see Appendix B)

\begin{tabular}{lllllll}
\hline Country & 2001 & & 2004 & & \multicolumn{2}{l}{2007} \\
\hline & FREI & FREI/GDPrrb & FREI & FREI/GDPrrb & FREI & FREI/GDPrrb \\
Hungary & 71.8 & 0.009 & 285.3 & 0.019 & 649.3 & 0.030 \\
Malaysia & 75.38 & 0.018 & 159.19 & 0.033 & 398.73 & 0.048 \\
Poland & 126.5 & 0.005 & 844.2 & 0.028 & $2,363.4$ & 0.046 \\
Denmark & 24.3 & 0.0009 & 324.7 & 0.008 & 1493.3 & 0.029 \\
Slovakia & 55.8 & 0.013 & 157.8 & 0.022 & 601 & 0.057 \\
Greece & 0.5 & 0.000 & 8.4 & 0.0002 & 149.8 & 0.003 \\
Turkey & 0 & 0.000 & 40 & 0.0008 & 449 & 0.004 \\
Czech & 256 & 0.032 & 656.3 & 0.049 & 1680 & 0.075 \\
China & 5136.5 & 0.044 & 5950.15 & 0.034 & 17088.7 & 0.050 \\
France & 1997.1 & 0.006 & 2614 & 0.005 & 6302.5 & 0.009 \\
\hline
\end{tabular}




\section{APPENDIX B}

FREI data sources

\begin{tabular}{|c|c|}
\hline Countries & Sources \\
\hline $\begin{array}{l}\text { Austria, Belgium, Czech, Denmark, Estonia, } \\
\text { Finland, France, Germany, Greece, Hungary, } \\
\text { Italy, Japan, Mexico, Netherland, Norway, Po- } \\
\text { land, Slovakia, Slovenia, Spain, South Korea, } \\
\text { Sweden, Turkey, UK, USA }\end{array}$ & $\begin{array}{l}\text { OECD Statistics, Globalization, Foreign Direct Investment Statistics, } \\
\text { available at: http://stats.oecd.org/Index.aspx }\end{array}$ \\
\hline China & $\begin{array}{l}\text { National Bureau of Statistics of China, available at: http://www.stats } \\
\text { gov.cn/english/statisticaldata/yearlydata/ }\end{array}$ \\
\hline Israel & $\begin{array}{l}\text { Accountant General's Office, Ministry of Finance, available at: http:// } \\
\text { www.bankisrael.gov.il/deptdata/pik_mth/pikmth_h.htm }\end{array}$ \\
\hline Romania, Thailand & Thomson Reuters Datastream \\
\hline Vietnam & $\begin{array}{l}\text { General Statistics Office of Vietnam, available at: http://www.gso.gov } \\
\text { vn/default_en.aspx?tabid=471 }\end{array}$ \\
\hline Taiwan & $\begin{array}{l}\text { Investment Commission, Ministry of Economic Affairs, available at: } \\
\text { http://www.moea.gov.tw/Mns/english/home/English.aspx }\end{array}$ \\
\hline Costa Rica & $\begin{array}{l}\text { Cordero and Paus (2008), available at: http://ase.tufts.edu/gdae/Pubs/ } \\
\text { rp/DP13Paus_CorderoApr08.pdf }\end{array}$ \\
\hline Malaysia & $\begin{array}{l}\text { Valuation and Property Services Department, Ministry of Finance, } \\
\text { available at: http://www.jpph.gov.my/V2/index.php?versi=1 }\end{array}$ \\
\hline
\end{tabular}

\section{APPENDIX C}

Descriptive statistics (before taking logarithm)

\begin{tabular}{lll}
\hline Variables & Mean & Standard Deviation \\
\hline FREI & $1,257.37$ & $3,398.64$ \\
RET & 2.54 & 0.90 \\
GDPcap & $27,537.95$ & $19,379.71$ \\
INFRAS & 53.75 & 23.27 \\
FINC & 6.84 & 4.23 \\
FDI & $24,107.13$ & $47,176.66$ \\
PPRIC & 629.03 & 185.17 \\
\hline
\end{tabular}

\section{APPENDIX D}

Regression with alternative measure of transparency and infrastructure

\begin{tabular}{ll}
\hline Dependent variable: lnFREI & \\
\hline Explanatory variables & GMM \\
\hline CC & 0.1535 \\
& $(1.0373)$ \\
lnGDPcap & $3.4992^{* * *}$ \\
& $(3.1188)$ \\
ROAD & 0.5352 \\
& $(1.6246)$ \\
FINC & -0.0124 \\
& $(-0.8621)$ \\
lnFDI & $0.9928^{* * *}$ \\
lnPPRIC & $(2.9132)$ \\
Test p-values & 1.1611 \\
Sargan Test & $(1.2461)$ \\
AR(2) & \\
\hline
\end{tabular}

Notes: Significant at: ${ }^{*} 10,{ }^{*} 5$ and ${ }^{* * *} 1 \%$; t-values reported in parentheses. 